late Lord Justice Baggallay, and he and his wife went to live for some time at Rope Hill in the New Forest. The New Forest, as was only natural, brought out all that passionate love of Nature and animal life which had already begun to show itself at Eton.

Like his life-long friend, Herbert St. Quintin, of Scampston Hall, Yorkshire, who died a year ago, Meade-Waldo was a born naturalist, and both were fortunate in having leisure to develop more and more their powers of observation in all branches of natural history. It is said that they corresponded almost every day of their lives and, needless to say, the subject of this correspondence formed an almost daily diary of what they had observed in the field of Nature. If the many facts comprised in these remarkable series of letters could be gathered up, it is probably no exaggeration to say that they would vie with those contained in White's "Natural History of Selbourne".

Both these friends were ardent hawkers and, in this fascinating pursuit, such other well-known hawkers and naturalists as Lord Lilford, Aubyn Trevor-Battye, W. R. Ogilvie-Grant, the Hon. Gerald Lascelles, Col. H. Barclay and the Rev. Gage Freeman and others, were very closely associated. Meade-Waldo's diaries contain many records of famous hawks and their prowess in the chase.

Meade-Waldo's life represents a page in the history of ornithology which is not likely to be rewritten. Another of his intimate friends was the late Henry Elwes, a man passionately fond of God's open spaces in many countries, a naturalist in every sense of the word, the author of one of the finest books on trees ever written. Lord Grey of Fallodon was another friend after his own heart, and Herbert St. Quintin, MeadeWaldo and Grey forgathered every year at Fallodon. All three have died in the last year and to those in sympathy with the point of view they represented, their passing will inevitably represent a lost link with the ornithology of the past.

But Meade-Waldo's activities in the realms of Nature were not confined to his own broad acres or those of his friends. He studied birds in Spain, as also in Morocco, where during a long residence he explored the Atlas Mountains in days when travel in that country was not the easy matter it is now. He was also intimately acquainted with the birds of the Canary Islands, and was one of the late Lord Crawford's guests on his voyage to Madagascar and the Comoro Group, in his famous yacht, the Valhalla.

Meade-Waldo was also an ardent supporter of the various societies for the protection of bird life, the fauna of the Empire, and the establishment of nature reserves, while he took the deepest interest in the welfare of the Zoological Society of London, of which he was a vice-president and a member of the Council. He was indefatigable in his attendance at the many meetings which such work involved.

\section{Mr. JoHN Power}

By the death on January 27, at Rosebank, near Cape Town, of Mr. John Power, one of the few remaining direct links with the Royal Observatory, Greenwich, under the administration of Sir George Airy, has been broken.

John Power was born in Waterford, Irèland, on July 14, 1860. He entered the Greenwich Observatory in 1875, six years before the retirement of Airy. In 1891 he left to take up the appointment of secretary and librarian to the Cape Observatory, under Sir David Gill. In 1895 he was appointed a junior assistant, being succeeded as secretary, after a short interval, by the late Dr. R. T. A. Innes, who afterwards became the first Union Astronomer. In 1905 Power was promoted to the rank of assistant. From 1897 until his retirement in 1920 he was in charge of the miscellaneous computing department. In that capacity he was responsible for the preparation and proof reading of the following catalogues (the dates of publication are in brackets):-Cape General Catalogue for 1890 (1898); the Cape General Catalogue for 1865 (1899); the Cape Astrographic Standard Star Catalogue (1906); the Cape Catalogues of Special Stars for 1900 (1906) ; the Cape Catalogue (Boss's Stars South of $-36^{\circ}$ ) (1907); the First Cape Fundamental Catalogue for 1900 (1915); the Second Cape Fundamental Catalogue for 1900 (1920); and the Cape Zone Catalogue of 20,843 stars for 1900 (1923). He showed remarkable industry and devotion in this work, spared no efforts to ensure accuracy in all details and was very skilled in marshalling large masses of numerical data. He rendered also very valuable services in connexion with the revision and control of the co-ordinates of the plates for the Cape zones of the Carte-duCiel work and in their preparation for press. For many years he was a regular and active observer with the transit circle.

Power was much interested in local and municipal affairs. He was largely responsible for the inception of a public library in Observatory (the suburb adjacent to and named after the Cape Observatory) of which he was chairman for many years preceding his death. He was also for many years a member of the Cape School Board, of which he became successively vice-chairman and chairman. After his retirement, he devoted a great deal of his time to the work of this body, on which he will be greatly missed. Financial approval for carrying out the programme of the Board was often difficult to obtain, but Power's Irish extraction showed itself in his love of a fight and he was at his best in defending his policy and attacking his opponents. The cause of elementary education at the Cape owes a great deal to his efforts.

Mr. Power was a widower and his only son, who had had a brilliant career at Oxford as a Rhodes scholar, was killed in action in East Africa. 